\title{
Growth and quality of Handroanthus serratifolius seedlings in soils incorporating amendments and inorganic residues ${ }^{1}$
}

\author{
Adriana Ribeiro de Oliveira ${ }^{2}$, Cácio Luiz Boechat ${ }^{2}$, Sarah Pricilla do Nascimento Amorim ${ }^{2}$, Manoel Emiliano \\ Lopes de Souza ${ }^{2}$, Lizandra de Sousa Luz Duarte ${ }^{2 *}(\mathbb{D})$, Helane França Silva ${ }^{2}$
}

$10.1590 / 0034-737 X 201966030010$

\begin{abstract}
Rock powder and boiler ash are residues with a high potential for the fertilization of substrates to produce forestry seedlings. They are the source of macro and micronutrients, besides having an effect on soil $\mathrm{pH}$. Therefore, this study aimed to evaluate the effect of the isolated application of rock power, boiler ash, dolomitic limestone and calcium carbonate on the reaction of soils with a sandy and clayey texture in the Cerrado Piauiense and on the growth and quality of ipê-amarelo seedlings. For this purpose, the $\mathrm{pH}$ values of soil in water and $\mathrm{CaCl}_{2}$ solution and the following morphophysiological parameters as indicators of the quality of forest seedlings were analyzed: length of the aerial part (LAP), and root (RL), stem diameter (SD), number of leaves (NL), total chlorophyll (TC), fresh mass of the aerial part (FMAP), fresh mass of the root (FMR), dry mass of the aerial part (DMAP), of the root (DMR) and total (TRM), and the DMAP/DMR and LAP/SD ratios and Dickson quality index (DQI). It was found that the rock powder and boiler ash residues change the $\mathrm{pH}$ values in clayey and sandy soils, and promote the growth and quality of ipê-amarelo seedlings.
\end{abstract}

Keywords: stone meal technique; ash; seedling production; textural class.

\section{INTRODUCTION}

Ipê-amarelo (Handroanthus serratifolius) is an initial secondary species. It is a deciduous plant, characteristic of semideciduous seasonal forests, cerrados, cerradões (Salomão et al., 2003), and it occurs with less frequency in caatinga areas. Its wood is commonly used for tool handles, civil construction and furniture. Since it adapts to dry soils with low chemical fertility it can also be used to recover degraded areas (Vieira \& Weber, 2017).

The tree has a high landscaping value because of its exuberant yellow flowers, and it stands out in the dry landscape in the months that precede the rainy season, besides being an ornamental plant that requires little in the way of cultivation. However, as a result of the logging, deforestation for agriculture and livestock purposes and the low germination of seeds, the natural occurrence of this species in Brazil has diminished (Oliveira et al., 2006; Oliveira et al., 2008).

The ipê-amarelo is propagated mainly by seminal route. Thus, as a result of the difficulties in germinating the seeds and the growing demand for good quality seedlings, it is necessary to formulate substrates that will promote the emergence, growth and quality of the seedlings (Goulart et al., 2017). Differently from plants cultivated for commercial purposes, there is little information regarding the germinative potential, development of native arboreal species seedlings and also about the composition of substrates (Afonso et al., 2012).

Various residues from industrial and agricultural processes with a high potential for pollution have been

\footnotetext{
Submitted on September 26 th, 2018 and accepted on June 25 2019.

${ }^{1}$ This work is part of the work of scientific initiation of the first author.

${ }_{2}^{2}$ Universidade Federal do Piaú, Campus Professora Cinobelina Elvas, Bom Jesus, Piauí, Brazil. adriana_riol@hotmail.com; cacioboechat@gmail.com; amorimspn1@gmail.com; manoel.agro.br@gmail.com; lizandrasousaluzduarte12@gmail.com; helane.engflo@gmail.com.

*Corresponding author: lizandrasousaluzduarte12@gmail.com
} 
outstanding as soil amendments and fertilizers, for instance, coconut powders, rice husks, sewage sludge, poultry bedding, and others (Trigueiro \& Guerrini, 2014; Alves et al., 2017; Bortolini et al., 2017). Among the main residues or byproducts are ashes from wood burning and powder of ornamental rocks since they have fertilizing and soil amendment properties, which has been widely documented in the scientific literature (Prates et al, 2010; Bonfim-Silva et al. 2013; Welter et al., 2011; Silva et al., 2012a; Raymundo et al., 2013).

Considering the need to reuse these residues and the low chemical fertility of the cerrado soils, the present study was performed to evaluate the effect of the isolated application of rock poweder, boiler ash, dolomitic limestone and calcium carbonate on the reaction of soils with a sandy and clayey texture in the Piauí Cerrado, and on the quality of the ipê-amarelo seedlings.

\section{MATERIAL AND METHODS}

The experiment was performed in a seedling nursery with $50 \%$ of shade, located at geographic coordinates $9^{\circ} 04^{\prime} 59,07^{\prime \prime} \mathrm{S}$ and $44^{\circ} 19^{\prime} 35,31^{\prime \prime} \mathrm{W}$. The climate in the region is classified as the $\mathrm{Cwa}$ type, which corresponds to a temperate and humid climate, with a dry winter and warm summer, according to the Köppen classification. The Table 1 shows the mean monthly values of the temperature and relative air humidity during the experimental period.

The soil samples were collected at a depth of $0-20$ $\mathrm{cm}$, after removing the organic layer present on the surface. Subsamples were air dried, homogenized, sieved with a $2 \mathrm{~mm}$ mesh opening, and then the physical and chemical characterization was performed according to the methodology described in Tedesco et al. (1995).

Soil samples were selected based on the grain size composition and the soils classified as Red-yellow Oxisol with a sandy texture and an Yellow Utisol with a clayey texture according to the Brazilian System of Soil Classification (Santos et al., 2013). The Table 2 shows the results of the chemical and physical analyses of the soils studied.

Table 1: Mean monthly air temperature $\left({ }^{\circ} \mathrm{C}\right)$ and relative humidity (\%) based on climatic conditions during the experimental period from November 2014 to February 2015

\begin{tabular}{lcc}
\hline Month & $\begin{array}{c}\text { Mean air } \\
\text { temperature } \\
{ }^{\circ} \mathbf{C}\end{array}$ & $\begin{array}{c}\text { Relative } \\
\text { humidity } \\
\%\end{array}$ \\
\hline November & 29.30 & 60 \\
December & 8.70 & 70 \\
January & 25.47 & 60 \\
February & 29.10 & 60 \\
\hline
\end{tabular}

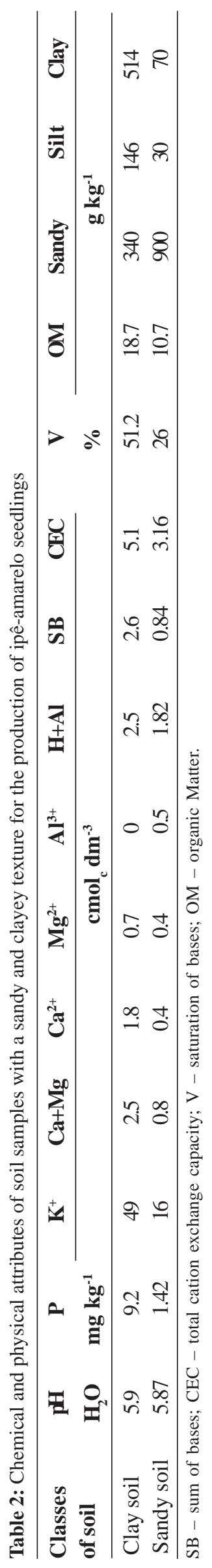


Two inorganic residues and two soil amendments were used to compose the substrates for seedling production. The inorganic residues were boiler ash resulting from burning vegetal biomass to produce heat to dry soy beans and powder of ornamental rocks produced by cutting marble and granite, both in the municipality of Bom Jesus - PI. The amendments tested were dolomitic limestone and calcium carbonate and PA magnesium with reactivities of $96 \%$ and $100 \%$, respectively. The chemical characterization of inorganic residues and amendments is shown in Table 3.

The ipê-amarelo seeds were obtained from ripe fruits collected from a single matrix plant and, then dried with full sun over the screen, until the pods opened. The seeds were conserved in a shady place until the time for sowing.

The experiment was conducted in a casualized block design with a $5 \times 2$ factorial scheme, with two inorganic residues, two soil amendments and a control treatment (without the incorporation of residues or amendments) and two textural classes (sandy and clayey), with five replicates.

Each experimental unit (EU) consisted of a perforated polyethylene bag, $20 \times 15 \mathrm{~cm}$, filled with a soil:residue or soil:amendment mixture. The residues and amendments were applied at a dose equivalent to $3 \mathrm{Mg} \mathrm{ha}^{-1}$ and immediately mixed until they were completely homogenized. The EU were wetted to close to $70 \%$ of the water retention capacity and replaced whenever necessary during 30 days, as a result of the time needed for the chemical reaction of treatments.

Seven days after the incorporation of inorganic materials the $\mathrm{pH}$ of soil in water and solution of $\mathrm{CaCl}_{2} 0.01$ $\mathrm{Mol} \mathrm{L}^{-1}$ was analyzed using the 1:2.5 ratio, and the reading was performed in the suspension (Embrapa, 2009). Sowing was performed using four seeds per experimental unit at a depth of $1 \mathrm{~cm}$. The plantules were thinned out 30 days after sowing, and only the visually most vigorous one per EU remained.

The evaluation of the morphophysiological quality of the seedlings occurred 90 days after sowing, based on the following parameters: lengths of the aerial part (LAP) and $\operatorname{root}(\mathrm{RL})$, both expressed in $\mathrm{cm}$, measured with a millimetric ruler, from the stem to the apical bud of the aerial part and from the stem to the end of the root, respectively; stem diameter (SD) expressed in $\mathrm{mm}$, measuring it with a digital pachymeter with $0.01 \mathrm{~mm}$ precision,; number of leaves (NL) expressed in unit; total chlorophyll (TC), measuring the relative index of chlorophyll using the SPAD portable chlorophyll meter; fresh masses from the aerial part (FMAP) and root (FMR) expressed in grams and determined on an analytic precision balance, dry masses of the aerial part (DMAP), root (DMR) and total (TDM), expressed in grams and determined on an analytic precision balance after drying in a forced air circulation oven at $65^{\circ} \mathrm{C}$ until constant weight.

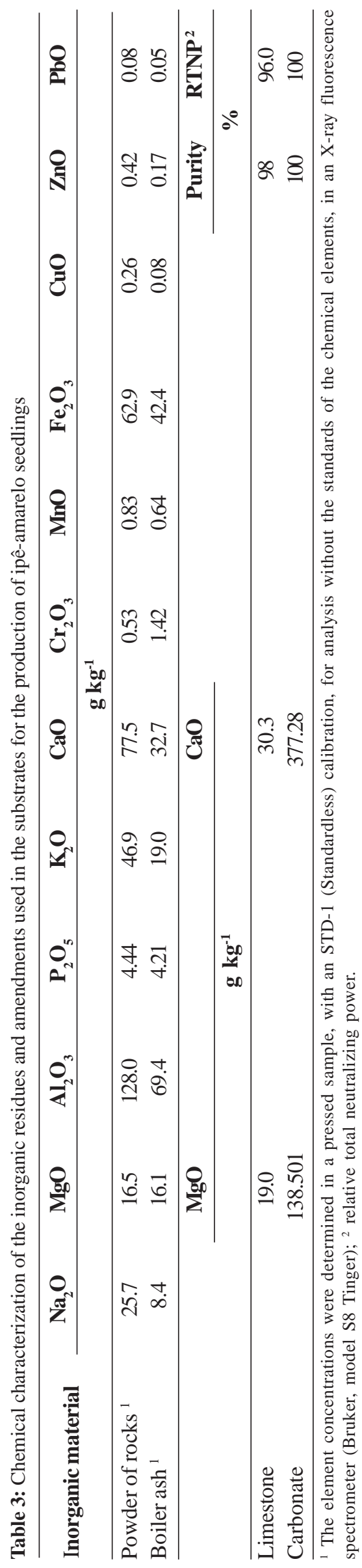

Rev. Ceres, Viçosa, v. 66, n.3, p. 235-242, mai/jun, 2019 
The ratio of dry mass from the aerial part to the dry mass of roots (DMAP/DMR); ratio of the height of the aerial part to the stem diameter (LAP/SD) and Dickson Quality Index (DQI) (Dickson et al., 1960) were also obtained by Equation DQI = TDM /((LAP/SD $)+\mathrm{MAP} /$ $\mathrm{DMR})$, where, $\mathrm{TDM}(\mathrm{g})=$ total dry mass; $\mathrm{LAP}(\mathrm{cm})=$ length of the aerial part; $\mathrm{SD}(\mathrm{mm})=$ stem diameter; $(\mathrm{DMAP})(\mathrm{g})=$ dry mass of the aerial part; DMR $(\mathrm{g})=$ dry mass of the root.

The data were submitted to the F test by analysis of variance (ANOVA) and the means, when significant, submitted to the Tukey test $(\mathrm{p}<0.05)$ employing the statistical program Sisvar (Ferreira, 2011).

\section{RESULTS AND DISCUSSION}

The $\mathrm{pH}$ values were influenced by the form of determination ( $\mathrm{pH}$ in water or in $\mathrm{CaCl}_{2}$ solution). In general, higher values were obtained using $\mathrm{pH}$ measured in water, as verified by Ebeling et al. (2008) in soils from several brazilian fields. The use of saline solution of $\mathrm{CaCl}_{2}$ results in lower $\mathrm{pH}$ values due to its greater concentration, provoking the displacement of $\mathrm{H}^{+}$from the surface of the colloids or hydrolysis of displaced $\mathrm{Al}^{3+}$ (Lacerda et al., 2017).

The mean values of $\mathrm{pH}$ in water in the two textural classes were altered by using the amendments and inorganic residues for the control. However, when the $\mathrm{pH}$ of the soils in a solution of $\mathrm{CaCl}_{2}$, was evaluated, there was a significant effect of treatments compared to the control only in the sandy soil (Table 4). The $\mathrm{pH}$ in water indicates the active acidity and, therefore, the weak acids contained in the soil did not appear in the determination of the $\mathrm{pH}$ in water.

Comparing the $\mathrm{pH}$ values in water of each treatment and texture, it was seen that in soil with a clayey texture the highest values were observed in the treatments with rock powder (6.37), limestone (6.00) and carbonate (6.19) and the lowest values were observed in the treatment with boiler ash and in the control. In sandy soil the $\mathrm{pH}$ values in water were in the following order: calcium carbonate and magnesium $(6.86)>$ limestone $(5.90)=\operatorname{control}(5.87)=$ ash (5.32) > rock powder (4.82). In the treatment incorporating rock powder there was a slight soil acidification, and the lowest value observed among the evaluated treatments (Table 4).

Silva et al. (2012b), observed a mean increase of 0.5 units of the $\mathrm{pH}$ with growing doses of basaltic rock powder of 10, 20, 50 and $100 \mathrm{Mg} \mathrm{ha}^{-1}$ in typical Nitisol developed from basalt and with $65 \%$ of clay in horizon A, corroborating the result in clayey soil, even at a lower dose of $3 \mathrm{Mg} \mathrm{ha}^{-1}$. However, in sandy soil the $\mathrm{pH}$ reduction may be related to the lower buffering power, which leads to faster acidification processes, causing the removal of the basic cations $(\mathrm{Ca}, \mathrm{Mg}, \mathrm{K}$ and $\mathrm{Na}$ ) from the soil system.
In a solution of $\mathrm{CaCl}_{2}$ it is found that in clayey soil there was no significant difference in the $\mathrm{pH}$ values. The buffering capacity of $\mathrm{pH}$ in soil is increased with an increment in its clay content. Thus, to amend clayey soils it is necessary to have larger doses to raise a $\mathrm{pH}$ unit as compared to sandy soils, when the neutralization method of $\mathrm{Al}^{3+}$ is used (Luz et al., 2002).

In soil with a sandy texture, the $\mathrm{pH}$ was higher when calcium carbonate was applied (Table 4), and there was no significant difference between the control and the treatments with rock powder and limestone. The lowest value (2.90) was observed in the treatment with ash. Different results were found by Bonfim-Silva et al. (2013), who, when applying increasing doses of up to $3.5 \mathrm{~g} \mathrm{dm}^{-3}$ of plant ash, from the burning of eucalyptus biomass used to heat a brewery boiler, observed an increase of 0.4 units of $\mathrm{pH}$ in $\mathrm{CaCl}_{2}, 30$ days after the incorporation.

The incorporation of calcium carbonate was outstanding among the two soil textures and the two methods of $\mathrm{pH}$ evaluation, and was among the most efficient treatments in raising the soil $\mathrm{pH}$ at the dose of 3 $\mathrm{Mg} \mathrm{ha}^{-1}$. However, even at the dose tested, the dolomitic limestone proved insufficient to raise the $\mathrm{pH}$ of these soils (Table 4).

There was no significant difference in the treatments within and between the two soil textural classes in variables

Table 4: $\mathrm{pH}$ values in water and $\mathrm{CaCl}_{2}$ in soils with different textures after the incorporation of inorganic residues and amendments for the production of ipê-amarelo seedlings

\begin{tabular}{lcc}
\hline \multirow{2}{*}{ Treatment } & \multicolumn{2}{c}{$\mathbf{p H}$ in $\mathbf{H}_{2} \mathbf{O}$} \\
\cline { 2 - 3 } & Clay soil & Sandy soil \\
\hline Powder of rocks & $6.37 \mathrm{aA}$ & $4.82 \mathrm{~dB}$ \\
Boiler ash & $5.87 \mathrm{bA}$ & $5.32 \mathrm{bcB}$ \\
Limestone & $6.00 \mathrm{abA}$ & $5.90 \mathrm{bA}$ \\
Carbonate & $6.19 \mathrm{abB}$ & $6.86 \mathrm{aA}$ \\
Control & $5.90 \mathrm{bA}$ & $5.87 \mathrm{bB}$ \\
\hline
\end{tabular}

C.V. $(\%) \quad 3.61$

\begin{tabular}{lcc}
\hline Treatment & \multicolumn{2}{c}{$\mathbf{p H}$ in $\mathbf{C a C l}_{2}$} \\
\cline { 2 - 3 } & Clay soil & Sandy soil \\
\hline Powder of rocks & $5.63 \mathrm{aA}$ & $3.76 \mathrm{bcB}$ \\
Boiler ash & $5.28 \mathrm{aA}$ & $2.90 \mathrm{cB}$ \\
Limestone & $5.30 \mathrm{aA}$ & $4.86 \mathrm{bA}$ \\
Carbonate & $6.05 \mathrm{aA}$ & $6.19 \mathrm{aA}$ \\
Control & $5.19 \mathrm{aA}$ & $3.74 \mathrm{bcB}$ \\
\hline C.V. $(\%)$ & 12.78 & \\
\hline
\end{tabular}

Means followed by the same letter are not different from each other according to Tukey's test at 5\% significance. Uppercase letters compare the soil texture in each treatment and the lower-case ones compare the treatments within each texture. C.V. - coefficient of variation. 
AP, SC and TC (Table 5). However, the values obtained in this experiment are similar to those obtained by Macedo $e t$ al. (2011) in ipê-roxo (Handroanthus impetiginosus) seedlings with different substrates and shadings and to those obtained by Goulart et al. (2017) when testing doses and nitrogenated sources in the production of ipê-amarelo seedlings. LAP is an excellent parameter to measure the quality of forest species seedlings, above all because it is easy and quick to measure and non-destructive. However, several studies have obtained contradictory results since this characteristic is variable because of the culture treatments and cultivation conditions in the nurseries (Gomes \& Paiva, 2004).

For the variable root length (RL) there was no significant difference among treatments in the clayey soil class. However, in sandy soil, the lowest values of this variable $(12.57$ and $15.80 \mathrm{~cm})$ were observed in the treatments with limestone and carbonate, respectively (Table 5). Meanwhile, significant differences were observed in the deployment of soil classes within the treatment. The seedlings produced in sandy soil in the treatments with rock powder and the control presented longer RL with values of 30.40 and $24.30 \mathrm{~cm}$, respectively, when compared to clayey soil. However, in the treatments with limestone and carbonate, a longer RL was observed in the seedlings cultivated in clayey soil with values of 24.70 and $26.77 \mathrm{~cm}$, respectively (Table 5).

The RL was shorter in the treatments that provided a greater elevation of the $\mathrm{pH}$ in $\mathrm{CaCl}_{2}$ in the sandy soil, however this is not seen in clayey soil (Tables 4 and 5). In the control treatment, it was observed that the root growth of seedlings that grew in the soil with a sandy texture was greater compared to that in the clayey soil. This characteristic shows the adaptive capacity of the species to the cerrado biome, where highly weathered soils, with a low $\mathrm{pH}$, chemically poor, and with low base saturation and acid character predominate (Loss et al., 2012).

Among the textural classes evaluated, the number of leaves (NL) was significantly higher only in the control treatment in sandy soil. There was no significant difference between the treatments within each textural class (Table 5). However, all treatments in the soil with a sandy texture fulfill a characteristic used by forestry companies to classify the quality of seedlings of native forest species, which is the number of leaves greater than three pairs (Paiva \& Gomes, 2000). This variable is essential for the uptake of luminous energy and conversion into chemical energy that, therefore directly influences the quality of the seedlings.

In the variable total chlorophyll (TC), the values obtained are between 29.52 and $38.60 \mu \mathrm{g} \mathrm{cm}^{-2}$ and there is no significant difference among the treatments and textural classes studied (Table 5). These results are similar and even superior to those observed by Macedo et al. (2011), evaluating the production of ipê-branco [Tabebuia roseoalba (Ridl.)] seedlings, in different substrates. According to Rêgo \& Possamai (2004) the TC in the leaves is often used to estimate the photosynthetic potential of the plants, because of its direct connection with the absorption and transfer of luminous energy. A plant with a high

Table 5: Biometrical parameters to evaluate the morphophysiological quality of the ipê-amarelo seedlings

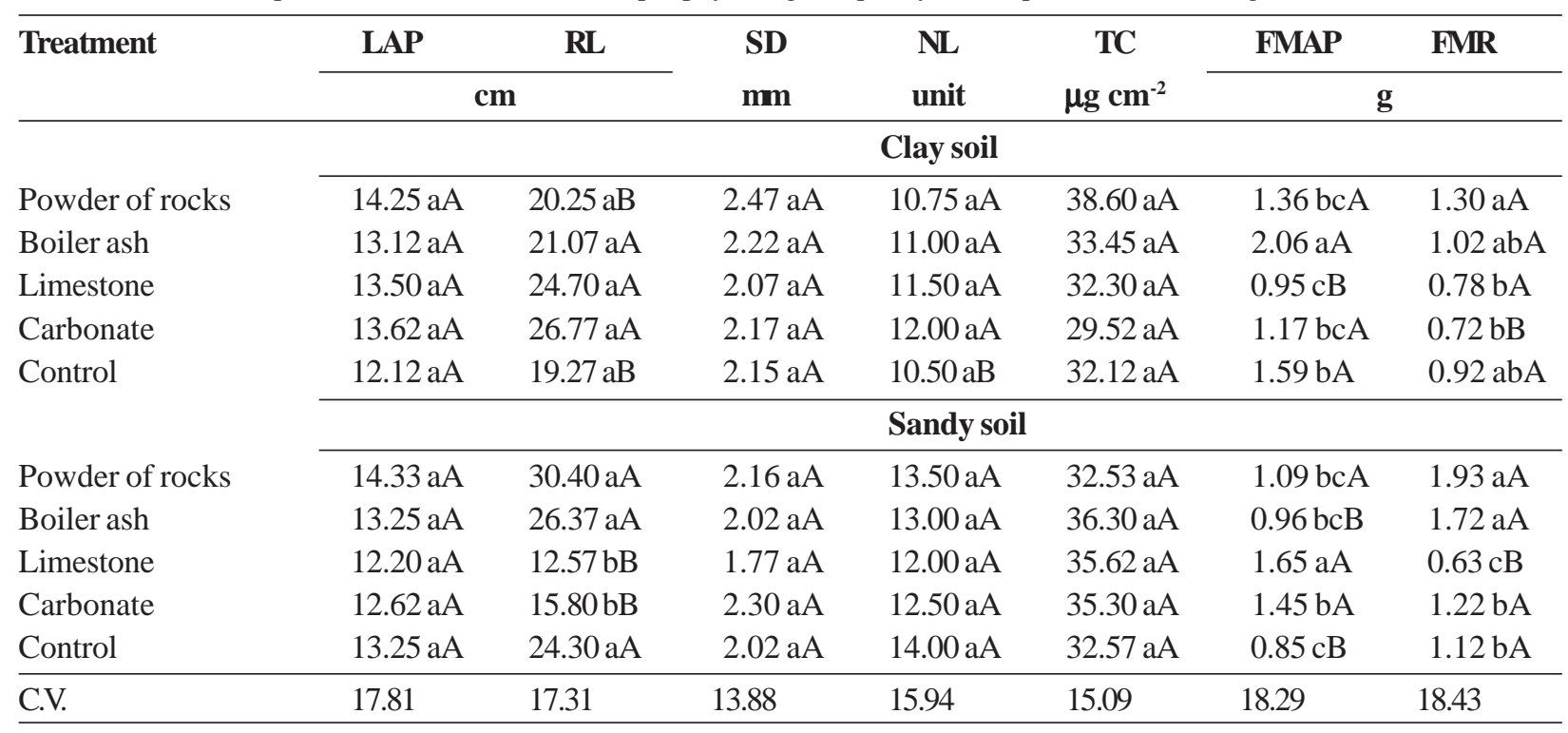

Means followed by the same letter are not different from each other according to Tukey's test at 5\% significance. Uppercase letters compare the soil texture in each treatment and the lower-case ones compare the treatments within each texture. LAP - Length of aerial part; RL - root length; SD - stem diameter; NL - number of leaves; TC - Total chlorophyll; FMAP - fresh mass of the aerial part and FMR - fresh mass of the root. 
concentration of chlorophyll can reach higher photosynthesis rates, because of its potential value to take up "quanta" in the time unit.

For the variable fresh mass of the aerial part (FMAP), a lower mean value was observed in the clayey textural class with limestone treatment and in the sandy one in treatments with ash and in the control. In the deployment of treatments within each textural class, the highest value of FMAP (2.06 $\mathrm{g}$ ) was observed in the treatment with ash and the lowest value $(0.95 \mathrm{~g})$, in the treatment with limestone. Meanwhile, in the sandy soil the highest value (1.65 g) was observed in the treatment with dolomitic limestone and the lowest value in the control $(0.85 \mathrm{~g})$ (Table 5).

Among the textures, only the treatments with calcium carbonate in sandy soil and limestone in clayey soil led to a smaller production of fresh mass of the root (FMR), causing a reduction of $44 \%$ and $21.74 \%$, respectively in relation to the controls, and there was no significant difference among the other treatments. Among the treatments evaluated in clayey soil, the highest values for FMR were $1.30 ; 1.02$ and $0.92 \mathrm{~cm}$ in the treatments with rock powders, ash and control, respectively, and the others did not present significant differences. In sandy soil the highest values of FMR were obtained with rock powder and boiler ash, which were, respectively 1.93 and $1.72 \mathrm{~g}$, followed by carbonate and the control, and the lowest value of FMR in the treatment with limestone (Table 5).

The production of dry mass of the aerial part (DMAP) in clayey soil was higher than in sandy soil in almost all treatments, except in treatment with calcium carbonate in which the DMAP was high in sandy soil. There was no significant difference among the treatments within each textural class (Table 6).

The yields of DMAP in clayey soil were higher than in sandy soil in almost all treatments, except in the treatment with calcium carbonate, in which DMAP was high in sandy soil. There was no significant difference among the treatments within each textural class (Table 6).

In general, the DRM was superior in sandy soil, except in the treatment with limestone, with a yield of $0.28 \mathrm{~g}$ in sandy soil and 0.31 in clayey soil. The higher yield of DRM in sandy soil may be a result of its low chemical fertility (Tables 2 and 6), lower water storage capacity and less resistance to penetration by the roots. Thus, the plants cultivated in this substrate tend to invest the greater part of the photosynthesis in their root system, providing better exploitation of the cultivated substrate.

In clayey soil the highest yield of DRM was achieved incorporating rock powder, without any significant difference among the other treatments. In sandy soil the highest productions of DRM were achieved in treatments with rock $(0.90 \mathrm{~g})$ and ash $(0.82 \mathrm{~g})$ and the lowest applying limestone $(0.28 \mathrm{~g})$ (Table 6$)$.
The total dry mass (TDM) presented different textures only in the treatments with ash and limestone, which promoted a smaller yield of TDM in clayey soil. There was no significant difference between the soil textures for this variable in the other treatments (Table 6).

In clayey soil the yield of TDM was superior in the treatments with rock powder, control and ash, with no statistical differences between them, and values of 1.38 , 1.09 and $1.04 \mathrm{~g}$ respectively. In sandy soil only, the application of limestone was different from the other treatments, presenting the lowest value of TDM. The highest TDM yields in the seedlings cultivated in substrates containing the residues could be a result of their fertilizing action, since both are sources of macro and micronutrients (Table 3 and 6). In sandy soil only, the limestone was applied differently from the other treatments and presented the lowest value of TDM. The higher yields of TDM in the seedlings cultivated in substrates containing the residues may be due to their fertilizing action, since they are both sources of macro and micronutrients (Tables 3 and 6).

The value of the DMAP/RDM ratio between the two textures was higher in clayey soil under the treatments with rock powder, ash and control, with no significant differences between the textures for this ratio when commercial amendments are applied. In clayey soil the highest value of the DMAP/RDM ratio was obtained in the control (2.27), and there was no significant difference between the other treatments. In sandy soil no difference was observed between the treatments applied for this parameter (Table 6).

According to Marques et al. (2006) the DMAP/RDM ratio is a reliable parameter to certify the quality of the seedling, and 2 (two), would be the best value for this ratio, independent of the species studied. In this sense, the best seedlings were obtained in clayey soil under treatments with ash, limestone, carbonate and control, with values of $2.10 ; 1.94 ; 2.02$ and 2.26 respectively.

For the LAP/SD ratio there was no significant difference between the treatments and the textural class studied (Table 6). However, this ratio is a commonly used parameter in the evaluation of the quality of forestry seedlings, inferring whether the seedling is weakened or hypertrophied. It also refers to the accumulation of reserves, which favor a better take of the seedlings in the field (Sturion \& Antunes, 2000). Besides being easily obtainable and non-destructive, the ratio indicates robustness and it is accepted as one of the most precise methodologies because it shows how vigorous the seedling is. In other words, the lower the value of LAP/ SD obtained, the greater the possibility of success of the seedlings in the field (Gomes \& Paiva, 2004).

For the Dickson Quality Index (DQI), among the soil textures the highest values were obtained in sandy soil 
Table 6: Morphological parameters to evaluate the quality of ipê-amarelo seedlings

\begin{tabular}{|c|c|c|c|c|c|c|}
\hline \multirow{2}{*}{ Treatment } & DMAP & DMR & TDM & \multirow{2}{*}{ DMAP/DMR } & \multirow{2}{*}{ LAP/SD } & \multirow{2}{*}{ DQI } \\
\hline & & $\mathbf{g}$ & & & & \\
\hline & \multicolumn{6}{|c|}{ Clay soil } \\
\hline Powder of rocks & $0.70 \mathrm{aA}$ & $0.67 \mathrm{aA}$ & $1.38 \mathrm{aA}$ & $1.07 \mathrm{bA}$ & $5.79 \mathrm{aA}$ & $0.20 \mathrm{aA}$ \\
\hline Boiler ash & $0.68 \mathrm{aA}$ & $0.35 \mathrm{bB}$ & $1.04 \mathrm{abB}$ & $2.10 \mathrm{abA}$ & $5.94 \mathrm{aA}$ & $0.13 \mathrm{bB}$ \\
\hline Limestone & $0.57 \mathrm{aA}$ & $0.31 \mathrm{bA}$ & $0.90 \mathrm{bA}$ & $1.94 \mathrm{abA}$ & $6.50 \mathrm{aA}$ & $0.10 \mathrm{bA}$ \\
\hline Carbonate & $0.65 \mathrm{aB}$ & $0.32 \mathrm{bB}$ & $0.98 \mathrm{bB}$ & $2.02 \mathrm{abA}$ & $6.17 \mathrm{aA}$ & $0.10 \mathrm{bB}$ \\
\hline \multirow[t]{2}{*}{ Control } & $0.75 \mathrm{aA}$ & $0.34 \mathrm{bB}$ & $1.09 \mathrm{abA}$ & $2.26 \mathrm{aA}$ & $5.69 \mathrm{aA}$ & $0.13 \mathrm{bA}$ \\
\hline & \multicolumn{6}{|c|}{ Sandy soil } \\
\hline Powder of rocks & $0.47 \mathrm{aB}$ & $0.90 \mathrm{aA}$ & $1.37 \mathrm{aA}$ & $0.52 \mathrm{aB}$ & $6.61 \mathrm{aA}$ & $0.19 \mathrm{abA}$ \\
\hline Boiler ash & $0.48 \mathrm{aB}$ & $0.82 \mathrm{abA}$ & $1.31 \mathrm{aA}$ & $0.61 \mathrm{aB}$ & $6.54 \mathrm{aA}$ & $0.18 \mathrm{abA}$ \\
\hline Limestone & $0.39 \mathrm{aB}$ & $0.28 \mathrm{~dB}$ & $0.68 \mathrm{bA}$ & $1.60 \mathrm{aA}$ & $7.19 \mathrm{aA}$ & $0.08 \mathrm{cB}$ \\
\hline Carbonate & $0.75 \mathrm{aA}$ & $0.59 \mathrm{bcA}$ & $1.36 \mathrm{aA}$ & $1.26 \mathrm{aA}$ & $5.50 \mathrm{aA}$ & $0.20 \mathrm{aA}$ \\
\hline Control & $0.50 \mathrm{aB}$ & $0.57 \mathrm{cA}$ & $1.08 \mathrm{aA}$ & $0.88 \mathrm{aB}$ & $6.53 \mathrm{aA}$ & $0.14 \mathrm{bA}$ \\
\hline C.V. & 20.07 & 22.01 & 15.91 & 37.06 & 17.35 & 17.39 \\
\hline
\end{tabular}

Means followed by the same letter are not different from each other according to Tukey's test at 5\% significance. Uppercase letters compare the soil texture in each treatment and the lower-case ones compare the treatments within each texture. DMAP - dry mass of the aerial part; DMR - dry mass of the root; TDM - total dry mass; DMAP/DMR ratio of dry mass of the aerial part and dry mass of the root; LAP/SD - ratio of the length of the aerial part and stem diameter and DQI - Dickson quality index of seedlings.

where almost all treatments had a result superior to or equal to the clayey soil except the application of limestone which resulted in a superior DQI in clayey soil. In clayey substrate the best DQI was obtained applying rock powder, and there was no difference between the control and the other treatments. On the other hand, in sandy soil the best values for this index were achieved applying carbonate, rock powder and ash with values of $0.2,0.19$ and 0.18 respectively (Table 6). DQI is considered a good indicator of seedling quality, because it uses robustness LAP/SD for calculation and equilibrium of the biomass distribution DMAP/DRM (Dickson et al., 1960).

\section{CONCLUSION}

Ornamental rock powder raises the $\mathrm{pH}$ in water of clayey textured soil and reduces the $\mathrm{pH}$ in soil with a sandy texture, and the boiler ash does not change the $\mathrm{pH}$ in water in both classes of soil used.

Calcium carbonate and magnesium are the only ones that can raise the $\mathrm{pH}$ of water in the two classes of soil at the dose tested.

Considering the robustness LAP/SD and the Dickson quality index (DQI), the ornamental rock powder and boiler ash are efficient to promote growth and quality of ipê-amarelo (Handroanthus serratifolius) seedlings.

The soil classes and type of material incorporated alter the morphological responses, especially when dry matter of ipê-amarelo seedlings is involved.

\section{ACKNOWLEDGEMENTS, FINANCIAL SUPPORT AND FULL DISCLOSURE}

The authors declare that they did not receive any type of funding to carry out this work and that there is no conflict of interest in carrying out the research and publishing the manuscript.

\section{REFERENCES}

Afonso MV, Martinazzo EG, Aumonde TZ \& Villela FA (2012) Composição do substrato, vigor e parâmetros fisiológicos de mudas de timbaúva [Enterolobium contortisiliquum (Vell.) Morong]. Revista Árvore, 36:1019-1026.

Alves MM, Alves EU, Araújo LR \& Lima MLS (2017) Substrate in the emergence and initial growth of seedlings of Caesalpinia pulcherrima. Ciência Rural, 47:e20150433.

Bonfim-Silva EM, Cabral CEA, Silva TJA, Moreira JCF \& Carvalho JCS (2013) Cinza vegetal: características produtivas e teor de clorofila do capim-marandu. Bioscience Journal, 29:1215-1225.

Bortolini J, Tessaro D, Gonçalves MS \& Oro SR (2017) Lodo de esgoto e cama de aviário como componente de substratos para a produção de mudas de Cedrela fissilis e Anadenanthera macrocarpa (benth). brenan. Revista Scientia Agraria, 18:121128.

Dickson A, Leaf AL \& Hosner JF (1960) Quality appraisal of white spruce and white pine seedling stock in nurseries. Forestry Chronicle, 36:10-13.

Ebeling AG, Anjos LHC, Perez DV, Pereira MG \& Valladares GS (2008) Relação entre acidez e outros atributos químicos em solos com teores elevados de matéria orgânica. Bragantia, 67:429-439.

Embrapa - Empresa Brasileira de Pesquisa Agropecuária (2009) Manual de análises químicas de solos, plantas e fertilizantes. $2^{\mathrm{a}}$ ed. Brasília, Embrapa Informação Tecnológica \& Rio de Janeiro, Embrapa Solos. 627p. 
Ferreira DF (2011) Sisvar: a computer statistical analysis system. Ciência e Agrotecnologia, 35:1039-1042.

Gomes JM \& Paiva HN (2004) Viveiros florestais - Propagação sexuada. $3^{\mathrm{a}}$ ed. Viçosa, Editora UFV. 116p.

Goulart LML, Paiva HN, Leite HG, Xavier A \& Duarte ML (2017) Produção de mudas de Ipê-amarelo (Tabebuia serratifolia) em resposta a fertilização nitrogenada. Revista Floresta e Ambiente, 24:e0137315.

Lacerda JJJ, Ratke RF, Dias KGL \& Sobrinho LS (2017) Química aplicada ao manejo do solo. In: Medeiros JC, Lacerda JJJ, Lopes GN \& Rosa JD (Eds.) Manejo de sistemas agrícolas no cerrado. Curitiba, Editora CRV. p. 65-86.

Loss A, Pereira MG, Beutler SJ, Perin A \& Anjos LHC (2012) Densidade e fertilidade do solo sob sistemas de plantio direto e de integração lavoura pecuária no Cerrado. Revista de Ciências Agrárias, 55:260-268.

Luz MJS, Ferreira GB \& Bezerra JRC (2002) Adubação e correção do solo: procedimentos a serem adotados em função dos resultados da análise do solo. Campina Grande, Embrapa Algodão. 35p. (Circular técnica, 63).

Macedo MC, Rosa YBCJ, Rosa Junior EJ, Scalon SPQ \& Tatara MB (2011) Produção de mudas de Ipê-branco em diferentes substratos. Cerne, 17:95-102.

Marques VB, Paiva HN, Gomes JM \& Neves JCL (2006) Efeitos de fontes e doses de nitrogênio no crescimento de mudas de sabiá (Mimosa caesalpiniaefolia Benth.). Scientia Forestalis, 71:77-85.

Oliveira AKM, Schleder ED \& Favero S (2006) Caracterização morfológica, viabilidade e vigor de sementes de Tabebuia aurea (Silva Manso) Benth. \& Hook. f. ex. S. Moore. Revista Árvore, $30: 25-32$.

Oliveira AKM, Schleder ED \& Favero S (2008) Caracterização morfológica, viabilidade e vigor de sementes de Tabebuia chrysotricha (Mart. ex. DC.) Standl. Revista Árvore, 32:10111018

Paiva HN \& Gomes JM (2000) Viveiros florestais - Propagação sexuada. $3^{\mathrm{a} e d . ~ V i c ̧ o s a, ~ E d i t o r a ~ U F V . ~ 116 p . ~}$

Prates FBS, Veloso HS, Sampaio RA, Junior GRZ, Lopes PSN, Fernandes LA \& Maio MM (2010) Crescimento de mudas de maracujázeiro-amarelo em resposta à adubação com superfosfato simples e pó de rocha. Revista Ceres, 57:239-246.
Raymundo V, Neves MA, Cardoso MSN, Brengonci IS, Lima JSSE \& Fonseca AB (2013) Resíduos de serragem de mármores como corretivo da acidez de solo. Revista Brasileira de Engenharia Agrícola e Ambiental, 17:47-53.

Rêgo GM \& Possamai E (2004) Avaliação dos Teores de Clorofila no Crescimento de Mudas do Jequitibá-Rosa (Cariniana legalis). Colombo, Embrapa Florestas. 04p. (Comunicado técnico, 128).

Salomão NA, Sousa-Silva JC, Davide AC, Gonzáles S, Torres RAA, Wetzel MMVS, Firetti F \& Caldas LS (2003) Germinação de sementes e produção de mudas de plantas do cerrado. Brasília, Rede de Sementes do Cerrado. 96p.

Santos HG, Jacomine PKT, Anjos LHC, Oliveira VA, Lumbreras JF, Coelho MR, Almeida JA, Cunha TJF \& Oliveira JB (2013) Sistema brasileiro de classificação de solos. $3^{\text {a }}$ ed. Brasília, Embrapa. 353p.

Silva DRG, Marchi G, Spehar CR, Guilherme LRG, Rein TA, Soares DA \& Ávila FW (2012b) Characterization and nutrient release from silicate rocks and influence on chemical changes in soil. Revista Brasileira de Ciência do Solo, 36:951- 962.

Silva A, Almeida JA, Schmitt C \& Coelho CMM (2012a) Avaliação dos efeitos da aplicação de basalto moído na fertilidade do solo e nutrição de Eucalyptus benthamii. Floresta, 42:69-76.

Sturion JA \& Antunes BMA (2000) Produção de mudas de espécies florestais. In: Galvão APM (Ed.) Reflorestamento de propriedades rurais para fins produtivos e ambientais. Colombo, Embrapa Florestas. p.125-150.

Tedesco MJ, Gianello C, Bissani CA, Bohnen H \& Volkweiss SJ (1995) Análises de plantas, solos e outros materiais. $2^{\mathrm{a}}$ ed. Porto Alegre, UFRGS. 174p.

Trigueiro RM \& Guerrini IA (2014) Utilização de lodo de esgoto na produção de mudas de aroeira-pimenteira. Revista Árvore, 38:657-665.

Vieira C \& Weber O (2017) Saturação por bases no crescimento e na nutrição de mudas de Ipê-Amarelo. Floresta e Ambiente, 24:e20160019.

Welter MK, Melo VF, Bruckner CH, Góes HTP, Chagas EA \& Uchôa SCP (2011) Efeito da aplicação de pó de basalto no desenvolvimento inicial de mudas de camu-camu (Myrciaria dubia). Revista Brasileira de Fruticultura, 33:922-931. 